\title{
BMJ Open An investigation into drug products withdrawn from the EU market between 2002 and 2011 for safety reasons and the evidence used to support the decision- making
}

Rhian McNaughton, ${ }^{1,2}$ Gwenaël Huet, ${ }^{1}$ Saad Shakir ${ }^{1,2}$

To cite: McNaughton $\mathrm{R}$, Huet G, Shakir S. An investigation into drug products withdrawn from the EU market between 2002 and 2011 for safety reasons and the evidence used to support the decision-making. BMJ Open 2014;4:e004221. doi:10.1136/bmjopen-2013004221

- Prepublication history for this paper is available online. To view these files please visit the journal online (http://dx.doi.org/10.1136/ bmjopen-2013-004221).

Received 10 October 2013 Revised 21 November 2013 Accepted 29 November 2013

CrossMark

${ }^{1}$ Drug Safety Research Unit, Southampton, UK

${ }^{2}$ University of Portsmouth, Portsmouth, UK

Correspondence to Dr Rhian McNaughton; rhian.mcnaughton@dsru.org

\section{ABSTRACT}

Objectives: The objective of this study was to determine the nature of evidence used to support the withdrawal of marketing authorisations of drug products for safety reasons throughout the European Union (EU) between 2002 and 2011.

Setting: Products withdrawn, either by a medicines agency or a marketing authorisation holder, during the period 2002-2011 were identified by conducting detailed searches of the WHO, the European Medicines Agency (EMA) and national medicines agency websites throughout the EU plus Norway, Iceland and Liechtenstein. The scientific evidence used to support the decision was identified from a search within PubMed, the EMA and national medicines agencies websites. Information about spontaneous case reports entered into EudraVigilance and unavailable on the EMA website was received by email from the EMA.

Results: 19 drugs were withdrawn from the market, throughout the EU, for safety reasons from 2002 to 2011. Case reports were cited in $95 \%$ of withdrawals (18/19) and case-control studies (4/19), cohort studies (4/19), randomised controlled trials (RCTs) (12/19) or meta-analysis $(5 / 19)$ were cited in $63 \%$ of withdrawals $(12 / 19)$. Cardiovascular events or disorders were the main reason for withdrawal $(9 / 19)$, followed by hepatic disorders (4/19) and neurological or psychiatric disorders (4/19).

Conclusions: This study has shown that the level of evidence used to support drug withdrawal has improved during the past 10 years, with an increased use of case-control studies, cohort studies, RCTs and meta-analyses. This research has demonstrated that such studies have contributed to decision-making in almost two-thirds of cases.

\section{INTRODUCTION}

The decision to remove a drug product from the market is not taken lightly either by the regulatory authority or the marketing authorisation holder. A number of reasons

\section{Strengths and limitations of this study}

- This study adds to the knowledge base regarding the level of evidence used to support decisions to remove drug products from the market.

- Results of this research are in line with the findings of other study groups which concluded that there has been a shift in the level of evidence used, for example, results of randomised controlled trials and cohort studies are used to justify a product withdrawal.

- English and French websites and publications were only searched.

- The international non-proprietary name of each drug was included in the PubMed search strategy but as various drug names exist for the same compound, a potential exists for the exclusion of some publications from contributing evidence.

contribute to the withdrawal such as the emergence of new safety evidence and significant drug interactions. Ultimately, the risk-benefit balance is paramount when making such decisions. The regulatory authorities review the evidence, such as spontaneous case reports or results from a randomised controlled trial (RCT) and prepare an opinion on whether the marketing authorisations of medicinal products containing that particular drug should be maintained, changed, suspended or withdrawn. The interpretation of the available safety data by the numerous competent authorities across the European Union (EU) is wide ranging as is the accessibility of information regarding how they reach their conclusion.

In 2005, legislation was introduced to ensure marketing authorisation holders complete a risk management plan (RMP) for their newly licensed product incorporating, where appropriate, post-marketing safety 
surveillance studies in the general population with regular assessment and appropriate reporting to the CHMP. ${ }^{1}$ The aim of the RMP is to ensure a more proactive approach to pharmacovigilance by putting in place measures that allow for the early detection and minimisation of risks throughout a medicine's lifecycle. This should, in theory, result in a reduction in the length of time for drug withdrawal should a safety issue arise. Risk management planning in the $\mathrm{EU}$ has been further enhanced by the introduction of new EU legislation for good pharmacovigilance practices which became applicable in July $2012 .^{2}$

Previous studies looked at the type of evidence used to support the withdrawal of products, for safety reasons, in different individual countries and over varying time periods. Arnaiz $e t a \hat{l}$ reported on products withdrawn in Spain between 1990 and 1999, Clarke et at for products in the USA and the UK from 1999 to 2001 and Olivier and Montastruc ${ }^{5}$ for medicines in France from 1998 to 2004. They all concluded that case reports were the mainstay of evidence used to support withdrawal decisions for pharmacovigilance reasons; case-control studies, cohort studies and RCTs were used as evidence in less than one-third of decisions. Paludetto $e t$ a ${ }^{6}$ revisited the issue 6 years later, between 2005 and 2011, and reported a shift in the level of evidence used. They determined that, of the 22 active substances withdrawn from the French market within this 6-year time frame, $68 \%$ of the decisions used multiple sources of evidence including clinical trials and pharmacoepidemiological studies. The objective of this study was to explore the level of evidence used to support the withdrawal of marketing authorisation of drug products in the time period 2002-2011 in the EU as a whole.

\section{METHODS}

Drug products withdrawn from the EU market for safety or pharmacovigilance reasons, either by a medicines agency or a marketing authorisation holder, during the period 2002-2011 were identified. This was established by carrying out detailed searches on the websites of the WHO, the European Medicines Agency (EMA) and those of national medicines agencies throughout the EU plus Norway, Iceland and Liechtenstein. The WHO Pharmaceutical Newsletter and the EMA press releases provided the most useable information. In addition, pharmaceutical companies were contacted to obtain more information concerning dates of withdrawal in specific countries.

Prescription and over-the-counter products were included if their marketing authorisation was withdrawn or suspended due to any safety reason such as an adverse drug reaction, abuse or misuse. Active ingredients contained in a combination product were also included. Veterinary products, herbal drugs, vaccines, excipients, biological drugs, radiopharmaceuticals products and diagnostic agents were excluded. Drugs were not included if only one particular dose, dosage form or indication was withdrawn.

The scientific evidence leading to the withdrawal decision was identified from a search within PubMed, the EMA website (published documents searched included: 'Press releases', 'Questions and Answers' and 'Scientific conclusions') and national medicines agencies websites. Within the 'Questions and Answers' reports and 'Press releases', prepared by the EMA, a summary of the reviewed evidence with reference to study type (eg, RCT, animal study) is often included. A request was also submitted to the EMA for information on the number of cases entered into EudraVigilance related to the reason of withdrawal for each drug.

A search strategy was developed in PubMed by first, searching under the International Non-proprietary Name (INN) of the drug. Second, if over 200 publications were found, the INN combined with the MeSH term describing the pharmacovigilance problem was entered. Third, the INN combined with the terms 'adverse drug reaction', 'adverse event', 'toxicity' and 'poisoning' was used. Furthermore, articles published up to 1 year after the drug withdrawals were included to account for the potential delay between the end of a study and its publication.

Data were collated from these sources and a comprehensive literature review was conducted. However, a fully systematic review was not carried out due to time and resource constraints. Any evidence cited in these sources was categorised according to study design including animal studies, case reports (including spontaneous case reports, published case reports and case series), casecontrol studies, cohort studies, RCTs, meta-analyses and other studies (including clinical trials not randomised and/or not controlled and incidence studies). Only studies where statistically significant results were found were included.

\section{RESULTS}

Nineteen drugs were withdrawn for pharmacovigilance reasons in the EU from 2002 to 2011 (table 1). The anatomical therapeutic chemical classes of drugs most represented in the nineteen drugs withdrawn are 'nervous system' (5/19 analgesics, antidepressants, antipsychotics and hypnotics), 'musculoskeletal system' (5/19 non-steroidal anti-inflammatory drugs (NSAIDs) and muscle relaxants) and 'alimentary tract and metabolism' (4/19 antidiabetics and antiobesity drugs).

The median time to withdrawal was 23 years with an IQR of 4 and 46 (table 1).

Case reports were cited in $95 \%$ of withdrawals $(18 / 19)$ and case-control studies (4/19), cohorts studies (4/19), RCTs (12/19) and meta-analysis (5/19) were cited in $63 \%$ of withdrawals (12/19; table 2$)$.

Cardiovascular events or disorders were the main reason for withdrawal $(9 / 19)$, followed by hepatic 
Table 1 List of drugs withdrawn for safety reasons in all EU member states between 2002 and 2011 grouped by adverse drug reaction or safety concern

\begin{tabular}{|c|c|c|c|c|c|}
\hline Drug name & Drug class or use & $\begin{array}{l}\text { Year first } \\
\text { marketed }\end{array}$ & $\begin{array}{l}\text { Year of } \\
\text { withdrawal }\end{array}$ & $\begin{array}{l}\text { Length of } \\
\text { time on } \\
\text { market } \\
\text { (years) }\end{array}$ & $\begin{array}{l}\text { Adverse reaction or } \\
\text { safety concern }\end{array}$ \\
\hline Rofecoxib & NSAID (COX-2 inhibitor) & 1999 & 2004 & 5 & Thrombotic events \\
\hline Thioridazine & $\begin{array}{l}\text { Neuroleptic ( } \alpha \text {-adrenergic and } \\
\text { dopaminergic receptor } \\
\text { antagonist) }\end{array}$ & 1958 & 2005 & 47 & Cardiac disorders \\
\hline Valdecoxib & NSAID (COX-2 inhibitor) & 2003 & 2005 & 2 & $\begin{array}{l}\text { Cardiovascular and } \\
\text { cutaneous disorders }\end{array}$ \\
\hline Rosiglitazone & $\begin{array}{l}\text { Antidiabetic treatment (PPAR } \\
\text { agonist) }\end{array}$ & 2000 & 2010 & 10 & $\begin{array}{l}\text { Cardiovascular } \\
\text { disorders }\end{array}$ \\
\hline Sibutramine & $\begin{array}{l}\text { Treatment of obesity } \\
\text { (serotonin-noradrenaline } \\
\text { reuptake inhibitor) }\end{array}$ & 1999 & 2010 & 11 & $\begin{array}{l}\text { Cardiovascular } \\
\text { disorders }\end{array}$ \\
\hline Orciprenaline & $\begin{array}{l}\text { Sympathomimetic } \\
\text { (non-specific } \beta \text {-agonist) }\end{array}$ & 1961 & 2010 & 49 & Cardiac disorders \\
\hline Benfluorex & Anorectic and hypolipidaemic & 1974 & 2009 & 35 & $\begin{array}{l}\text { Heart valve disease- } \\
\text { Pulmonary } \\
\text { hypertension }\end{array}$ \\
\hline Clobutinol & $\begin{array}{l}\text { Cough suppressant (centrally } \\
\text { acting) }\end{array}$ & 1961 & 2007 & 46 & QT prolongation \\
\hline Buflomedil & $\begin{array}{l}\text { Vasodilator ( } \alpha 1 \text { and } \alpha 2 \\
\text { receptor antagonist) }\end{array}$ & 1974 & 2011 & 37 & $\begin{array}{l}\text { Neurological and } \\
\text { cardiac disorders } \\
\text { (sometimes fatal) }\end{array}$ \\
\hline Veralipride & $\begin{array}{l}\text { Neuroleptic (and dopaminergic } \\
\text { receptor antagonist) }\end{array}$ & 1979 & 2007 & 28 & $\begin{array}{l}\text { Neurological and } \\
\text { psychiatric disorders }\end{array}$ \\
\hline Rimonabant & $\begin{array}{l}\text { Treatment of obesity } \\
\text { (cannabinoid receptor } \\
\text { antagonist) }\end{array}$ & 2006 & 2008 & 2 & Psychiatric disorders \\
\hline Carisoprodol & Muscle relaxant & 1959 & 2007 & 48 & $\begin{array}{l}\text { Intoxication- } \\
\text { Psychomotor } \\
\text { impairment- } \\
\text { Addiction-misuse }\end{array}$ \\
\hline $\begin{array}{l}\text { Aceprometazine + } \\
\text { Acepromazine + } \\
\text { Clorazepate }\end{array}$ & Hypnotic & 1988 & 2011 & 23 & $\begin{array}{l}\text { Cumulative adverse } \\
\text { effects-misuse-- } \\
\text { fatal side effect }\end{array}$ \\
\hline Dextropropoxyphene & Opioid painkiller & $\sim 1960$ & 2009 & 49 & Fatal overdose \\
\hline Nefazodone & Antidepressant & 1994 & 2003 & 9 & Hepatotoxicity \\
\hline $\begin{array}{l}\text { Ximelagatran/ } \\
\text { melagatran }\end{array}$ & $\begin{array}{l}\text { Anticoagulant (thrombin } \\
\text { inhibitor) }\end{array}$ & 2003 & 2006 & 3 & Hepatotoxicity \\
\hline Lumiracoxib & NSAID (COX-2 inhibitor) & 2003 & 2007 & 4 & Hepatotoxicity \\
\hline Sitaxentan & $\begin{array}{l}\text { Antihypertensive (endothelin } \\
\text { receptor antagonist) }\end{array}$ & 2006 & 2010 & 4 & Hepatotoxicity \\
\hline Bufexamac & NSAID & $\sim 1970$ & 2010 & 40 & $\begin{array}{l}\text { Contact allergic } \\
\text { reactions }\end{array}$ \\
\hline
\end{tabular}

disorders $(4 / 19)$ and neurological or psychiatric disorders $(4 / 19)$.

A list of the adverse drug reactions reported in EudraVigilance, correlating to the safety issue given as the reason for withdrawal for each drug product is shown in table 3. No results were returned for ximelagatran/melagatran on querying the database for hepatotoxicity reports which is in line with the EMA assessment which states that an RCT (EXTEND) study ${ }^{7}$ elucidated this safety concern. ${ }^{8}$ A high number of reports were recorded for rosiglitazone; 10834 cases of cardiac disorders associated with its use.

\section{DISCUSSION}

This study has shown that the strength of evidence used to support the withdrawal of products relied on information recorded from spontaneous reporting together with 
Table 2 List of evidence used to support medicinal product withdrawals in all EU member states between 2002 and 2011 derived from EMA reports, PubMed literature search and websites of competent authorities

\begin{tabular}{|c|c|c|c|c|c|c|c|}
\hline Drug name & $\begin{array}{l}\text { Case } \\
\text { reports }\end{array}$ & $\begin{array}{l}\text { Animal } \\
\text { studies }\end{array}$ & $\begin{array}{l}\text { Case- } \\
\text { control }\end{array}$ & Cohort & RCTs & Meta-analysis & ${ }^{*}$ Others \\
\hline Rofecoxib & $x$ & & $x$ & $x$ & $x$ & $x$ & \\
\hline Thioridazine & $x$ & $\mathrm{X}$ & $x$ & & $x$ & $x$ & \\
\hline Valdecoxib & $x$ & & & & $x$ & $x$ & \\
\hline Rosiglitazone & $x$ & & $x$ & $x$ & $x$ & $x$ & \\
\hline Sibutramine & $x$ & & & & $x$ & & $x$ \\
\hline Orciprenaline & $x$ & & & & $x$ & & \\
\hline Benfluorex & $x$ & & $x$ & $x$ & $x$ & & \\
\hline Clobutinol & $x$ & $x$ & & & $x$ & & \\
\hline Buflomedil & $x$ & $X$ & & & & & \\
\hline Veralipride & $x$ & & & & & & \\
\hline Rimonabant & $x$ & & & & $x$ & $x$ & \\
\hline Carisoprodol & $x$ & $x$ & & $x$ & $x$ & & $x$ \\
\hline $\begin{array}{l}\text { Aceprometazine+Acepromazine } \\
+ \text { Clorazepate }\end{array}$ & $x$ & & & & & & $x$ \\
\hline Dextropropoxyphene & $x$ & & & & & & $x$ \\
\hline Nefazodone & $x$ & & & & & & $x$ \\
\hline Ximelagatran/melagatran & & & & & $x$ & & \\
\hline Lumiracoxib & $x$ & & & & $x$ & & \\
\hline Sitaxentan & $x$ & $x$ & & & & & \\
\hline Bufexamac & $x$ & $x$ & & & & & $x$ \\
\hline
\end{tabular}

other pharmacoepidemiological and clinical research studies. All decisions to revoke marketing authorisations described in this study utilised spontaneous case reports, except for the withdrawal of ximelagatran. ${ }^{8}$ Spontaneous case reporting remains central to pharmacovigilance as it allows for the detection of suspected adverse drug reactions and significant safety signals. However, spontaneous reporting should be used in conjunction with other pharmacovigilance methodologies such as observational studies and clinical trials to further evaluate any such safety signals due to the potential for over and under-reporting, confounding, bias and misclassification. The RCT is commonly assumed to be the gold standard for clinical research ${ }^{9}$ but adverse drug reactions may not become evident until a medicine is used in the larger population, post-authorisation, where patients are more likely to have comorbidities and other risk factors. The outcome of pharmacoepidemiology studies and the conduct of systematic reviews, even with their limitations particularly bias, confounding and misclassification, can provide useful additional evidence on the nature and frequency of adverse drug reactions. As a direct country comparison, Clarke et $a l^{4}$ stated that six products were withdrawn in the UK in between 1999 and 2001, namely grepafloxacin (marketed for 2 years), cisapride (12 years), pumactant (6 years), cerivastatin (4 years), droperidol (30 years) and levacetylmethadol (4 years). The median length of time these drugs remained on the UK market was 5 years (IQR 4-10.5). Droperidol was available for approximately 30 years as it was marketed before the licensing system began in 1971 (personal communication from MHRA (2013)). In contrast, only three products were withdrawn from the UK market between 2009 and 2011; orciprenaline, sibutramine and rosiglitazone marking a $50 \%$ reduction in the number of drug products withdrawn over the same time period. The median length of time these products remained on the market was 11 years (IQR 10.5-30). Although the length of time taken to withdraw a drug product appears to have doubled (mainly due to the length of time orciprenaline was available, 49 years) over the 10-year period, the evidence used to aid the decision-making has been heightened. Spontaneous case reporting was used to support the case for withdrawal in five of the six products between 1999 and 2001, while only one RCT was included as evidence. ${ }^{4}$ In this study, spontaneous case reporting and RCTs were shown to have contributed to all three withdrawn products, which suggests an increase in the level of evidence used to support decisions for drug product withdrawal from the market.

The findings of this study are in line with those of the study conducted by Paludetto et at in 2012 who observed a shift in the nature of the safety data used as justification for the withdrawal of products in France in the time periods 1998-2004 and 2005-2011. One explanation the authors gave for this change was the implementation of the European Clinical Trial Directive in 2004 and the subsequent analysis of clinical trial safety data by pharmacovigilance experts. The evolution of pharmacovigilance legislation over the past decade is 
Table 3 Count of case reports of selected withdrawn drug products submitted to EudraVigilance up to 30 June 2012

\begin{tabular}{|c|c|c|c|}
\hline Drug name & MedDRA level & Term & Total \\
\hline Rofecoxib & PT & Myocardial infarction & 6711 \\
\hline \multirow[t]{2}{*}{ Thioridazine } & HLGT & Cardiac arrhythmias & 179 \\
\hline & PT & Sudden death & 28 \\
\hline \multirow[t]{2}{*}{ Valdecoxib* } & SOC & Skin and subcutaneous tissue disorders & 317 \\
\hline & SOC & Cardiac disorders & 313 \\
\hline Rosiglitazone* & SOC & Cardiac disorders & 10834 \\
\hline \multirow[t]{2}{*}{ Sibutramine } & PT & Blood pressure increased & 69 \\
\hline & $\mathrm{PT}$ & Heart rate increased & 23 \\
\hline Orciprenaline & HLGT & Cardiac arrhythmias & 15 \\
\hline \multirow[t]{2}{*}{ Benfluorex } & HLGT & Cardiac valve disorders & 3439 \\
\hline & PT & Pulmonary hypertension & 181 \\
\hline Clobutinol & HLGT & Cardiac arrhythmias & 14 \\
\hline \multirow[t]{3}{*}{ Buflomedil } & HLGT & Cardiac arrhythmias & 36 \\
\hline & HLGT & Fatal outcomest & 14 \\
\hline & HLGT & Seizures (including subtypes) & 35 \\
\hline \multirow[t]{2}{*}{ Veralipride } & HLGT & Anxiety disorders and symptoms & 142 \\
\hline & HLT & Depressive disorders & 221 \\
\hline \multirow[t]{2}{*}{ Rimonabant* } & SOC & Psychiatric disorders & 918 \\
\hline & PT & Depression & 545 \\
\hline \multirow[t]{2}{*}{ Carisoprodol } & HLGT & Mental impairment disorders & 18 \\
\hline & HLGT & Movement disorders (including parkinsonism) & 15 \\
\hline $\begin{array}{l}\text { Aceprometazine+Acepromazine+ } \\
\text { Clorazepate }\end{array}$ & HLGT & Fatal outcomes & 3 \\
\hline \multirow[t]{2}{*}{ Dextropropoxyphene } & HLGT & Fatal outcomest & 55 \\
\hline & HLGT & Overdoses & 91 \\
\hline Nefazodone & HLGT & Hepatic and hepatobiliary disorders & 16 \\
\hline Ximelagatran/melagatran & \multicolumn{3}{|c|}{ No results were returned } \\
\hline Lumiracoxib & HLGT & Hepatic and hepatobiliary disorders & 92 \\
\hline \multirow[t]{2}{*}{ Sitaxentan* } & PT & Hepatitis & 8 \\
\hline & PT & Hepatic failure & 6 \\
\hline Bufexamac & SOC & Immune systems disorders & 10 \\
\hline
\end{tabular}

likely to have contributed to the availability of additional data through the conduct of post-marketing safety surveillance allowing regulators and companies to include such information in the drug products safety portfolio. It is difficult to ascertain whether the introduction of RMPs for newly licensed medicinal products has influenced the length of time a drug with safety concerns remains on the market as only two drug products included in this study were marketed after 2005. Rimonabant and sitaxentan were licensed in 2006 and removed from the market in 2008 and 2010, respectively. At the time of authorisation, information was known about the psychiatric side effects of rimonabant ${ }^{10}$ and liver toxicity associated with sitaxentan ${ }^{11}$ and the benefit-risk balance deemed to be favourable. However, in the case of rimonabant, as data became available when used in the real-life clinical setting, the risk of obese and overweight patients developing psychiatric side effects was double that of patients taking placebo. ${ }^{10}$ The marketing authorisation holder voluntarily removed sitaxentan from the market and cancelled ongoing clinical trials as a result of two cases of fatal liver injury. ${ }^{11}$
During the time period studied, an additional 12 drugs were withdrawn in some but not all EU countries. In some cases, it was not feasible to establish the reasons for the withdrawal, for example, astemizole has been withdrawn from the UK, France and Spain, but information about its availability in other EU countries is difficult to establish. Another example, the NSAID nimesulide, was withdrawn in Spain, Finland, Belgium and Ireland but is still available in $15 \mathrm{EU}$ member states. The EMA had a favourable opinion of the risk-benefit balance after a review of spontaneous reports of epidemiological studies and other published studies in $2010 .^{12}$ This was in spite of evidence of an increased risk of hepatotoxicity compared with other NSAIDs, although restrictions are in place to limit the number of liver-related side effects. Ultimately, it would seem that there is a disparity in opinion of risk-benefit within the EU between decision-makers at the EMA and various regulatory authorities.

The main limitation of this study was the impact of various language barriers across the EU. Websites of competent authorities are written in their local language 
and resource constraints did not allow for translations. Only information from the websites of those competent authorities where English and French are spoken locally or an English or French version is available was utilised. This may also have had a bearing on the studies included as evidence in this research as again only English and French publications were included. After a website search, competent authorities and pharmaceutical companies were contacted in order to obtain further information on drug product withdrawals. The response rate from competent authorities was $70 \%$ and from pharmaceutical companies 55\%. Again, this may have been due to a language barrier problem, but it may also be due to a lack of available information on drugs withdrawn for several years or an unwillingness to share information. Competent authorities or companies may also not have a complete list of products removed from the market. Over time, the way in which drug products have been licensed in the EU has changed considerably. It is relatively easy to determine how products licensed centrally were withdrawn from the market. However, for drugs that have been licensed for a considerable number of years, in countries that have recently joined the EU, and for those that have multiple drug names, it can be very difficult to obtain conclusive, consistent and clear information. The effect of different drug names may have led to potential exclusions of study evidence from our PubMed search strategy as the INN of each drug was used rather than an exhaustive drug name list. Owing to time constraints, it was not possible to conduct a full investigation into why drug products had been removed from the market in some but not all countries and to find detailed information about the decision-making process.

It would be useful to investigate the impact of the introduction of RMPs in a future study. This could be carried out as an investigation of how results from postmarketing studies, conducted as part of RMPs, aid in the assessment of any safety issues. In theory, the introduction of RMPs should expedite post-marketing drug safety decisions.

This study has shown that the strength of evidence has improved during the past 10 years. Indeed, the results show an increased use of case-control studies, cohort studies, RCTs and meta-analyses as justification for the withdrawal of a marketed product. Previously, only one-third of decisions used evidence from observational studies or clinical trials ${ }^{4}$ but this study showed that they had contributed to decision-making in almost two-thirds of withdrawals. Spontaneous case reports remain the most significant method of pharmacovigilance.

Acknowledgements The Drug Safety Research Unit (DSRU) is a registered independent charity (No.327206) associated with the University of Portsmouth. The companies have no control on the conduct or the publication of its studies. The DSRU has received such funds from the manufacturers of products included in this study.
Contributors RMN, SS and GH were all involved in the conception and design of the study, interpretation of data, drafting and revision of the article and final approval of the version for publication. GH and RMN were responsible for data acquisition.

Funding The DSRU receives unconditional donations from pharmaceutical companies.

Competing interests SS reports personal fees from ICON (Contract research organisation), personal fees from Shire Pharmaceuticals, personal fees from ONO Pharmaceuticals, personal fees from Intermune Pharma, personal fees from IPSEN, outside the submitted work; GH reports personal fees from Axpharma, personal fees from Thea laboratories, outside the submitted work.

Provenance and peer review Not commissioned; externally peer reviewed.

Data sharing statement No additional data are available.

Open Access This is an Open Access article distributed in accordance with the Creative Commons Attribution Non Commercial (CC BY-NC 3.0) license, which permits others to distribute, remix, adapt, build upon this work noncommercially, and license their derivative works on different terms, provided the original work is properly cited and the use is non-commercial. See: http:// creativecommons.org/licenses/by-nc/3.0/

\section{REFERENCES}

1. European Medicines Agency (EMA) online. 2013. http://www ema europa eu (accessed 28 Mar 2013).

2. European Medicines Agency (EMA). Guideline on good pharmacovigilance practices (GVP) Module V-Risk management systems. 2013. http://www ema europa eu/docs/en_GB/document library/Scientific_guideline/2012/06/WC500129134 pdf (accessed 16 May 2013).

3. Arnaiz JA, Carné X, Riba N, et al. The use of evidence in pharmacovigilance. Case reports as the reference source for drug withdrawals. Eur J Clin Pharmacol 2001:57:89-91.

4. Clarke A, Deeks JJ, Shakir SA. An assessment of the publicly disseminated evidence of safety used in decisions to withdraw medicinal products from the UK and US markets. Drug Saf 2006;29:175-81.

5. Olivier P, Montastruc JL. The nature of the scientific evidence leading to drug withdrawals for pharmacovigilance reasons in France. Pharmacoepidemiol Drug Saf 2006;15:808-12.

6. Paludetto MN, Olivier-Abbal P, Montastruc JL. Is spontaneous reporting always the most important information supporting drug withdrawals for pharmacovigilance reasons in France? Pharmacoepidemiol Drug Saf 2012;21:1289-94.

7. Agnelli G, Eriksson BI, Cohen AT, et al.; EXTEND Study Group. Safety assessment of new antithrombotic agents: lessons from the EXTEND study on ximelagatran. Thromb Res 2009;123:488-97.

8. European Medicines Agency (EMA). Press Release: AstraZeneca Withdraws its Application for Ximelagatran 36-mg film-coated tablets. 2013. http://www ema europa eu/docs/en_GB/document_library/ Press_release/2010/02/WC500074073 pdf (accessed 15 Mar 2013).

9. Carne X, Arnaiz JA. Methodological and political issues in clinical pharmacology research by the year 2000. Eur J Clin Pharmacol 2000;55:781-5.

10. European Medicines Agency (EMA). Assessment Report for Acomplia (Rimonabant). 2009. http://www ema europa eu/docs/en GB/document library/EPAR - Assessment Report - Variation/ human/000666/WC500021280 pdf (accessed 28 Mar 2013).

11. European Medicines Agency (EMA). Press release: Thelin (sitaxentan) to be withdrawn due to cases of unpredictable serious liver injury. 2010. http://www ema europa eu/ema/index jsp?curl=/ pages/news_and_events/news/2010/12/news_detail_001161 jsp\&murl=menus/news and events/news and events jsp\&mid=WC0b01ac058004d5c1 (accessed 28 Mar 2013).

12. European Medicines Agency (EMA). Questions and answers on the review of systemic medicines containing nimesulide. 2012. http:// www ema europa eu/docs/en_GB/document_library/Referrals document/Nimesulide_31/WC500107957 pdf (accessed $28 \mathrm{Mar}$ 2013). 